\title{
what's new? a first appraisal of the juncker commission
}

\section{hussein kassim}

School of Politics, Philosophy, Language and Communication Studies The University of East Anglia, Norwich Research Park Norwich, NR4 7TJ

United Kingdom

E-mail: h.kassim@uea.ac.uk

\begin{abstract}
Although still in its early phases, the Juncker Commission has already broken new ground. Not only is Jean-Claude Juncker the first Commission President to be selected by the Spitzenkandidaten process, an extra-constitutional system that has reconfigured the European Union's institutional balance, but he has transformed the structure and operation of the College in order to create a more political, and therefore more effective, Commission, and made good - so far - on his promise 'to do better on the bigger things and be small on the small things'. This article examines this three-fold transformation. It looks at the innovations and change associated with the Juncker Commission. It considers what motivated them and how they were achieved, sets them in historical perspective, and discusses their implications for the institutions and for the EU more broadly.
\end{abstract}

Keywords Juncker Commission; European Commission; European Commission Presidency; Spitzenkanditaten 
Although still at an early stage of its five-year term, the Juncker Commission is already one of the most noteworthy in the history of the European Union (EU). Its President, Jean-Claude Juncker, is the first to be nominated to the office as a result of the Spitzenkandidaten process, a system intended to mobilise interest in elections to the European Parliament and to enhance the EU's legitimacy by linking the election results to the appointment of the European Commission. The new Commission President, moreover, has instituted a radical overhaul of the Commission's architecture. He has restructured the College, redefined its working methods and internal operation, and sought to create a political Commission that is capable of meeting the severe challenges that confront the EU. Furthermore, although other Commission Presidents have vowed to do 'less, better', few have been able to deliver. Building on the expansion of the Commission Presidency by José Manuel Barroso, and learning from his predecessor's experience over two terms, Juncker appears well positioned to fulfil his election promise: to be 'bigger and more ambitious on big things, and smaller and more modest on small things'.

It is also important to note the significance of the Juncker Presidency for conceptual arguments about EU leaders and EU leadership (see Helms, in this issue). First, in his conduct and interpretation of what the Spitzenkandidaten process implies, Juncker is the first Commission President to be able to claim a personal, electoral mandate. Although he was not directly elected by the citizenry and it would be difficult to contend that Juncker as Commission President has the same democratic credentials as a national political leader, the legitimacy that Juncker derives from his method of election makes him a unique figure in transnational governance. Second, the sometimes dramatic changes that Juncker has enacted in his early period in office demonstrate a high level of individual initiative and autonomy. The agency that Juncker has shown runs somewhat counter to the emphasis a number of authors have placed on the structural constraints confronting EU leaders (Hayward, 2008), and specifically the Commission President (Cramme, 2011: 43-44; Majone, 2014: 247-253), 
suggesting that the leadership capacity of the office may have been underestimated).

Focusing on the changes that he has introduced, this paper offers an early evaluation of the Juncker Commission. It examines the Commission President's path to office, looks at the composition, structure and operation of the College, and considers the Commission's policy programme. It compares Juncker's approach to the Presidency to his predecessors and reflects on the historical significance of the Juncker Presidency for the development of the presidential office. It also considers the impact and implications of the innovations that characterise the Juncker Commission. In the spirit of Reinalda and Verbeek (2014: 603-604), cited by Helms (this issue), it takes an actor-, rather than an institution-, centred approach to leadership.

\section{CAREER, NOMINATION AND ELECTION}

Like his three immediate predecessors - Jacques Santer, Romano Prodi and José Manuel Barroso - Jean-Claude Juncker is a former Prime Minister. ${ }^{1}$ In common with three of the four - Prodi is the exception - he is a Christian Democratic and member of the European People's Party (EPP). Other aspects of his background and experience, however, make him somewhat unusual even among this company. The longest-serving prime minister in the EU, Juncker succeeded Jacques Santer to the premiership of the Grand Duchy in 1995 when the latter was nominated to succeed Jacques Delors as Commission President. He remained in office, presiding over coalitions of various compositions until 2013, when he announced the resignation of his government. $^{2}$

In addition to his longevity as prime minister, Juncker has broader ministerial experience than most of his predecessors, ${ }^{3}$ as well as a longer history of close involvement in the EU; hence, the Financial Times's description of him a 'long-time EU eminence grise' (Spiegel, 2014). When he assumed the premiership, Juncker retained his responsibilities as minister for work and employment, and finance minister. As a result, he has been closely involved in the 
single currency since its inception and has made significant interventions in other areas of EU policy since the late $1990 \mathrm{~s}$. As finance minister at the time of the Maastricht intergovernmental conference negotiations (IGCs), Juncker was one of the architects of economic and monetary union. In 2005 he became the first president of the Eurogroup of Eurozone finance ministers and continued in that role until $2014 .{ }^{4}$ In that capacity, he played a key role in negotiating the bailouts following the financial and economic crisis. As minister for work and employment, he was one of the draughtsman of the European Employment Strategy or 'Luxembourg process'.

\section{THE SPITZENKANDIATEN'REVOLUTION',}

In institutional terms, it is Juncker's route from candidate to appointment as Commission President that distinguishes him most sharply from his predecessors. ${ }^{6}$ All other Commission Presidents were appointed by common accord of heads of state of government, subject (since the Treaty of the European Union) to approval by the European Parliament. Juncker was one of five 'lead candidates' - Spitzenkanditaten - each selected by their party to play a key part in the elections to the European Parliament and to be its nominee for Commission President. As a result, Juncker's appointment was more protracted, more public, and more political than that of previous presidents. It also distinguishes him and his office sharply from other transnational leaders.

The Spitzenkandidaten system is an extra-constitutional process championed by advocates of a more direct linkage between European elections and the appointment of the Commission in the interests of enhancing the EU's legitimacy. It was advanced following the introduction of the Lisbon Treaty, and is the latest episode in which the European Parliament has taken advantage of formal rules to extend its own influence by establishing a political convention that it is difficult for other institutions to constrain or reverse. The emergence of the Spitzenkandidaten system is best understood in the context of efforts on the part of the EU's 
political leaders since Maastricht to respond to perceptions of a democratic deficit by strengthening the European Parliament.

The process began when the Treaty of European Union made consultation by member governments of the European Parliament compulsory before they proceeded to the nomination of the person they intended to appoint as Commission President. The College was then 'subject as a body to a vote of approval by the European Parliament' (Article 158(2)). Although the procedures for approving the College were amended by the Treaty of Amsterdam and the Treaty of Nice, ${ }^{7}$ the nomination process remained unchanged until the Lisbon Treaty. The latter introduced three changes: the European Council would propose a candidate 'taking into account the elections to the European Parliament'; the European Council will act by qualified majority; and the candidate 'shall be elected by the European Parliament by a majority of its component members. ${ }^{, 8}$

Although the Lisbon Treaty extended the power of the European Parliament, it did not create the connection between the results of the European elections and the appointment of the European Commission that proponents of greater EU parliamentarianization had proposed. Primary among them, the European People's Party (EPP) had called for a direct linkage since the Laeken Declaration launched the 'Future of Europe' debate in 2001 (EPP 2014). In October 2002, on the eve of the Constitutional Convention at its Estoril Congress, which was attended by ten EPP prime ministers, including José Manuel Barroso the then prime minister of Portugal, ${ }^{9}$ the EPP proposed in its 'Constitution for a Strong Europe' that: 'A candidate for the President of the European Commission should be proposed to the European Parliament by the European Council in light of the outcome of European elections, and by qualified majority vote' (emphasis added).' The Convention Praesidium adopted a looser wording, however, requiring only that the European Council should take the results of the European elections into account. This was the formulation that would reappear in the draft Constitutional Treaty and, ultimately, in the Lisbon Treaty. 
The EPP continued to support its more radical alternative and argued that European parties should choose a candidate for the Commission Presidency, who would lead its campaign in the European elections. In both 2004 and 2009, the EPP declared Barroso its candidate, then in November 2012 EPP President, Wilfred Martens, announced that the party would select a candidate for the 2014 elections. With the approach of 2014, Commission President Barroso and Vice-President Reding - both EPP members - made similar calls: the first in his State of the Union 2012 address (Barroso, 2012), the second in a Commission Recommendation (Commission, 2013). An accompanying communication to the latter explained that Spitzenkandidaten 'would make concrete and visible the link between the individual vote of the EU citizens for a candidate for membership of the European Parliament and the candidate for President of the Commission supported by the party of the candidate MEP. This would help EU citizens to better understand which candidate for President of the Commission their vote will ultimately support. It would increase the legitimacy of the President of the Commission and more generally, the democratic legitimacy of the whole EU decision-making process' (Commission, 2013). In November 2012 the European Parliament (2012) adopted a resolution arguing along similar lines. Calling on European political parties to nominate candidates for the Commission presidency ahead of the 2014 elections, a further resolution adopted on 4 July 2013 asserted that the candidate put forward by the party that wins the most seats in the EP 'will be the first to be considered' for the post of President of the European Commission.

As the 2014 European electives approached, five European political parties agreed to select 'lead candidates'. ${ }^{10}$ The Party of European Socialists was the first. It selected Martin Schulz, the President of the European Parliament, as their candidate. The Liberals (Guy Verhofstadt), European Greens (Ska Keller and José Bové) and the Party of the European Left (Alex Tsipras) followed suit. The EPP, with 12 prime ministers as well as Commission President Barroso and President of the European Council, Herman van Rompuy, in office was 
the last to make its choice. Both Chancellor Merkel and Herman van Rompuy expressed thir reservations, however, on the grounds that it shifted power away from the European Council towards the European Parliament (Spiegel, 2014a).

According to supporters of the Spitzenkanditaten concept, there was no question after the EPP emerged from the polls on 25 May as the leading party, with 212 seats of the 751 seats, that Juncker should become Commission President. This view was challenged by David Cameron, who had voiced his objections throughout. The British prime minister was opposed to Juncker, whom he saw as an arch-federalist, although he was also concerned about the European Council's loss of appointment power. London claimed to have the support of Budapest and Stockholm, while Chancellor Merkel was known to harbour reservations. Following reports that she had come under pressure for 'betraying the voters and democracy in favour of back-room deals' (Wagstyl, 2014), Merkel eventually declared her support for Juncker. At its meeting on 27 June, the European Council nominated Juncker Commission President by 26 votes to 2, with Cameron and Hungarian prime minister, Viktor Orban, voting against ${ }^{11}$ - the first time a Commission President had not been nominated by unanimity.

Having been nominated by the European Council, Juncker needed a majority to be elected by the European Parliament. As he required 376 votes, Juncker was forced to look beyond the EPP for support. The programme, 'A New Start for Europe: My Agenda for Jobs, Growth, Fairness and Democratic Change', that Juncker presented to the plenary on 15 July 2014 (Juncker, 2014a), was designed to appeal to a broad constituency. In setting out not only the actions he thought the Commission should take, but the working methods necessary for their delivery, Juncker drew on and expanded the priorities on which he had based his campaign. ${ }^{12}$ In the event, he more than surpassed the threshold, with 422 votes.

\section{REFLECTIONS ON THE SPITZENKANDIDATEN PROCESS}

Although too early for an exhaustive analysis, it is worth considering some of its effects and 
implications of the Spitzenkanditaten procedure. ${ }^{13}$ First, there can be little doubt that the European Parliament won its contest with the European Council. Christiansen (2015) argues the European Parliament prevailed because it was generally united and because its President gave his relentless support to the process. The heads of state and government, by contrast, were divided and had no alternative candidate. Schimmelfennig (2014) suggests that it would have been difficult for the European Council to withstand the normative weight of the argument that the lead candidate has an electoral mandate. Even if member governments had decided to resist, the European Parliament could have threatened to block any alternative candidate proposed by the European Council. It is difficult to see how the Spitzenkanditaten process could be rolled back and, therefore, it appears that the development of this extraconstitutional mechanism has enabled the European Parliament to secure appointment power over the Commission President. ${ }^{14}$

The wider implications are significant. The Spitzenkanditaten system displaces the European Council, which as Laffan contends, 'is the core of the Union's political authority and centre of its legitimacy' (European Parliamentary Research Service 2014). It also undermines the Commission's claim to independence, on which Majone $(1996,1998)$ has argued the legitimacy of the institution rests. Even if Juncker has followed the tradition of composing the College as a 'super coalition' (see below), his successors may not, with the danger that the institution that has historically claimed to embody the European interest may become identified with a particular party group. Juncker's emphasis on the mandate he has secured from the European Parliament will certainly make it difficult for the Commission to maintain an equidistant position between the Parliament and the European Council.

At the same time, although few would claim that the Spitzenkandidaten process ignited popular interest in the European elections ${ }^{15}$ - indeed, turnout in 2014 at 42.61 per cent was marginally lower than the 2009 figure of 42.97 per cent - it was a more political process than the traditional method and did instigate a wider debate. To that extent, as Christiansen 
contends, it has the potential for developing the European public sphere (European Parliamentary Research Service, 2014). Certainly, candidates were forced to engage more broadly and intensively than ever before. Juncker, for example, contested a party primary, in which he defeated the then Commissioner for the Internal Market, Michel Barnier. He constructed and campaigned on a platform of explicit objectives and participated in nine 'presidential' debates with other candidates in the run-up to the elections. ${ }^{16} \mathrm{He}$ also mobilised a cross-party majority in the European Parliament which required him to be responsive to the demands of parties (and voters) other than his own. It is difficult to deny that Juncker has a mandate for his 'political Commission' or that he has a claim to a strong measure of personal legitimacy.

\section{A RESTRUCTURED COLLEGE}

The method by which its President's was chosen is only the first novelty of the Juncker Commission. In line with his vision of a 'political Commission', dynamic and effective, Juncker has enacted a radical restructuring of the College. Recruitment of seasoned politicians to the new tier of Vice Presidencies has been an important element.

\section{NEW HOLES FOR NEW PEGS}

The Commission President decides on the structure and operation of the College, and allocates portfolios, but depends on member governments to nominate candidates. Conscious of the need for a Commission to deliver, Juncker departed from tradition and looked to recruit seven Vice-Presidents. Whereas the title had been largely honorary in previous Commissions, under Juncker it comes with responsibility for policy coordination, symbolized by reservation of the right of the right to submit agenda items for discussion at meetings of the College to the Vice-Presidents.

The new structure was designed to overcome weaknesses, old and new. A tier of senior 
politicians in Vice-President posts would ensure the spread of political responsibility among a team of experienced individuals, used to political pressure, managing competing policy demands, and dealing with the media. A complaint of the Barroso Commission had been that Commissioners had tended to become invisible, particularly in its second term, and were rarely available to explain Commission policy. The delegation of particular policies to individual Vice-Presidents also made clear exactly who was responsible for their delivery. Most importantly, however, the new structure was intended to give the Commission the strong political leadership it had lacked for much of its history. Although the Commission's centre had been significantly strengthened since the late 1990s, the process of presidentialization that took place under the two Barroso Commissions (Kassim, 2012, Kassim et al, 2013, Kassim et al 2015) did not necessarily strengthen the collective capacity of the College to ensure effective policy delivery. The creation of a tier of Vice-Presidents to head policy groupings represents a strategy of shared leadership and responsibility intended to 'ensure a dynamic interaction of all Members of the College' and that '[t]he directors-general, all highly competent, have to obey their Commissioners and not the other way round' (Juncker, 2014c). A further aim of compelling Commissioners to work together was to strengthen political leadership and prevent 'divide and rule' strategies on the part of Director Generals, and thereby to overcome the Commission's fragmentation along departmental lines. As Juncker explained: '[Commissioners] will work together in a spirit of collegiality and mutual dependence. I want to overcome silo-mentalities and introduce a new collaborative way of working in areas where Europe can really make a difference.'

This new model was radical, first, because it appeared to depart from the convention that all Commissioners are equal, ${ }^{17}$ even if Juncker denied that this was the case: 'In the new Commission, there are no first or second-class Commissioners - there are team leaders and team players.' Second, although groups of Commissioners were nothing new - Hallstein had used them in the first College, as in the more recent past had Prodi and Barroso - the idea of 
flexible, fluid and overlapping teams was an innovation. Third, the new structure raised issues of command and accountability. Since Vice-Presidents would be responsible for coordinating policy, but would not have direct responsibility for managing individual services, the new system created more complex arrangements between individual Commissioners and the administration. Finally, the new structure represented a novel way of ensuring that all Commissioners would have meaningful functions. The expansion of the College as result of enlargement had led to a multiplication of portfolios, which created agenda inflation, further coordination problems, and minor or redundant responsibilities.

\section{FROM NOMINATION TO APPROVAL}

Juncker's thinking about the structure of the Commission became apparent as he sought nominations for the College from the member states. The multiple and repeated leaking of organigrams, which showed roles for Vice-Presidents and the definition of portfolio responsibilities, sometimes with the names of potential designates pencilled in, appears to have been part of a gaming process over the summer, whereby the Commission President and his transition team sought to encourage national capitals to offer suitable candidates, to provoke them into re-thinking their nominations where the Commission President thought them not appropriate, or to incentivise the inclusion of more women with the promise that women would be appointed to senior portfolios. ${ }^{18}$

The release of draft organograms was also a device to test ideas - whether the single market should continue as a portfolio, dividing economic responsibilities between two Commissioners, and whether energy and climate could be combined - as well to prepare the outside world for surprises. ${ }^{19}$ When the full team of Commissioners-designates was announced on 10 September (Juncker, 2014b), accompanied by a press release and memo outlining the proposed working methods of the College (Commission, 2014a, 2014b), some pairings still provoked a response. Either they appeared to involve a conflict of interest - for 
example, Jonathan Hill, the UK nominee and Commissioner-designate for financial services, where the UK has a strong interest and had been concerned to protect the City of London and Miguel Arias Cañete, the Spanish Commissioner-designate for energy and climate change, despite his connections with the oil industry - or were simply considered inappropriate - for example, Tibor Navracsics, the Hungarian Commissioner-designate for education, culture and human rights, when he had been a member of a government that was held to have led an assault on civil rights.

Indeed, these issues did emerge with others in the hearings. ${ }^{20}$ Hill was summoned to an unprecedented second hearing to allay concerns about his impartiality, while Pierre Moscovici's candidacy was challenged over his ability to impose budgetary discipline on France when he had been part of a government in Paris that had run a deficit. Cañete was called to account not only on account of commercial interests in the oil industry, but for alleged comments made about a female rival. Questions were also levelled against the Czech Commissioner-designate for Justice, Věra Jourová, and, the former Slovenian prime minister, Alenka Bratušek, Juncker's proposed Vice-President for Energy Union, who as interim premier put her own name forward despite having lost the election. Navracsics also came under challenge.

Following consultation and negotiations with party leaders in the European Parliament, which led to a number of concessions - a practice that has become an established part of the process $^{21}$ - Juncker was able to push through Cañete, Hill, and Moscovici. However, when Bratušek withdraw her candidacy following her rejection by the European Parliament, Juncker was obliged to ask Ljubijana for a replacement. Juncker assigned Slovenia's new Commissioner-designate, Violeta Bulc, to transport, and switched Maros Šefčovič - a returning Commissioner, who had already appeared before the EP transport committee - from the transport portfolio and nominated him Vice-President for energy union, the role originally envisaged for Bratušek. After the parliamentary committee had rejected Navracsics for the 
Education, Culture, Youth and Citizenship portfolio, Juncker transferred the citizenship portfolio to Dimitris Avramopoulos, the Greek Commissioner-designate for home affairs, but allowed the Hungarian Commissioner-designate to retain Education, Culture and Youth. Although in response to concerns expressed by Members of the European Parliament (MEP) on the left he agreed to switch responsibility for pharmaceuticals (initially assigned to the commissioner-designate for industry, Elżbieta Bieńkowska) to the Commissioner-designate for Health, Vytenis Andriukaitis, and sustainable development from Cañete to Timmermans, Juncker insisted on maintaining the division between economic and social responsibilities that MEPs on the left had questioned.

Juncker presented his team and political priorities before a plenary session of the European Parliament on 22 October. In his speech (Juncker, 2014c) he warned that his Commission represented the 'last chance' to win back the trust of European citizens and made clear that his Commission would be 'more political' than the current one. Addressing concerns on both political wings, Juncker once again underlined his commitment to transparency and to cutting back on excessive bureaucracy. Four-hundred-and-twenty-three MEPs voted in favour, with the largest three groups - the EPP, the Socialists and Democrats, and ALDE - broadly in support, with 209 votes against (mainly from the Greens, the European United Left, and Europe of Freedom and Direct Democracy groups), while 67 MEPs, mainly from the conservative ECR group, ${ }^{22}$ abstained. On the following day, the European Council (2014) adopted the decision appointing the European Commission to serve from 1 November 2014 until 31 October 2019.

\section{THE JUNCKER COMMISSION}

The incoming Commission President was largely successful in his ambition to appoint experienced politicians. ${ }^{23}$ The new College included nine former prime ministers or deputy prime ministers, nineteen former ministers, three former foreign ministers, seven former 
Commissioners, and eight former MEPs. Its members are drawn from four political parties: 14 from the EPP, one from the ECR, 8 from the Socialists and Democrats, and 5 from ALDE. ${ }^{24}$ There are seven Vice-Presidents. Alongside Federica Mogherini, who as the High Representative must under the Treaty be a Vice-President and who will head the policy group on, two Vice-Presidents have over-arching responsibilities: Kristalina Georgieva, Commissioner responsible for the Budget; and Frans Timmermans, who as First VicePresident, for subsidiarity and better regulation - competences that resonate with the exercise that he conducted as Foreign Minister of the Netherlands in the wake of the Dutch 'no' in the referendum on the draft Constitutional Treaty. The other four Vice-Presidents head policy groups: Jyrki Kaitainen - jobs, growth and investment; Valdis Dombrovskis - a deeper and fairer EMU; Andrus Ansip - a digital single market; and MarošŠefčovič - energy union and climate change (see Table 1).

>>> about here: Table 1. The Juncker Commission. Vice-Presidents and project teams.

One respect in which Juncker was less successful, however, was in delivering a better gender balance. His Commission has the same number (nine) as his predecessor. Juncker was well aware of this failing, reporting to the European Parliament that:

'I had to fight to get the national governments to put forward nine female members. At the end of July . . . we had three women designated by their governments. I had to persuade quite a few governments to send a woman Commissioner, and I had to turn down quite a few male candidates: I won't say who they were because I wouldn't wish to embarrass the prime ministers whom I managed to persuade to put forward a woman. But in all honesty, nine women out of 28 Commissioners is still ridiculously 
low.'

\section{ORGANIZATION AND WORKING METHODS}

Juncker's vision of how the new Commission should operate was explained to incoming members of the Commission and the administration. Bilateral meetings with Commissionersdesignate were followed by mission letters that set out the Commission's 'new way of working' and the importance for it to make 'a fresh start' ${ }^{25}$ For each Commission, the letters set out portfolio-specific objectives, with a timetable. They emphasized the need for members of the Commission to abide by the highest professional and ethic standards, the commitment to transparency, and the importance of close working relations with the European Parliament and the member states. Working methods were also discussed at a preparatory seminar held for the College in Brussels on 11 and 12 September, formalised in a communication from the Commission President to members of the Commission in November 2014, and explained in briefings to Directors General.

Three other organizational changes are noteworthy. First, Commissioners in the same policy group have been assigned offices on the same floors in the Berlaymont building. The hope is that physical propinquity will encourage coordination. Second, the size of Commissioners' private offices has been reduced. Commissioners are allowed six member of cabinet plus a communications officer, though the Vice-Presidents can have seven and the First Vice-President eight. Importantly, since they have not been assigned services, the work of the Vice-Presidents will be supported by the Secretariat General, which accordingly has been allocated 80 new members of staff. Third, communications - a weak spot of the Commission $^{26}$ - has been overhauled in an effort to ensure greater coordination and effectiveness. The spokesperson service has been reduced to a staff of 15 , so that Commissioners no longer have their own spokesperson, all spokespersons will be present at 
the midday briefing, and each spokesperson is responsible for a particular policy area. It has a new head in Margaritis Schinas and is directly responsible to the Commission President. More broadly, there is a general expectation that Commissioners will appear frequently before the press, and that Commissioners will visit each of the member states to explain EU policy on the ground.

\section{Will it work?}

The reorganization of the Commission around Vice-Presidents represents an innovative and audacious attempt to address a long-standing organizational problem. It required quick learning on the part of Vice-Presidents, particularly those new to the Commission, effective support since they do not have the expertise of a Directorate General on which to rely, ${ }^{27}$ and goodwill among Commissioners within each policy group, particularly on the part of portfolio Commissioners. Unsurprisingly, since there are obvious fault lines, ${ }^{28}$ tensions between Commissioners have already been reported (see, e.g. Keating, 2015; Rinaldi, 2014). The test is not whether there are differences among Commissioners with intersecting responsibilities, but whether the policy groups can develop workable and effective policy initiatives that can be driven through by the services.

\section{POLICIES AND PERFORMANCE}

Although far too early to reach a judgment on the policy success or otherwise of the Juncker Commission, five observations can be made about its performance thus far. First, activity has been tightly focused on the delivery of Juncker's ten strategic priorities (Juncker, 2014a). The Commission work programme for 2015 was structured accordingly (Commission, 2015a - see Table 2). Presented by Commission President Juncker and Vice-President Timmermans, the work programme was remarkable both for its parsimony - it envisaged only 23 initiatives - 
and because, in a sharp departure from previous practice and in line with the better regulation agenda, it announced the withdrawal of 80 pending proposals. ${ }^{29}$ The scrapping of legislation was not without controversy. Although Timmermans stressed that the Commission had not included anything that could not be achieved in 2015, there was an angry response of the part of some MEPs, especially in relation to two measures aimed at limiting air pollution and rules on waste (Keating, 2014).

>> about here: $\quad$ Table 2. Commission President Juncker's Political Guidelines and the 2015 Work Programme

In its first few months, the Commission has made a promising start to the implementation of the programme. Among the most important initiatives, the $€ 315$ billion infrastructure investment plan - a flagship of the growth and jobs element of the Commission President's programme - was announced on 24 November (Commission, 2014c), and guidance on the Growth and Stability Pact in January 2015. The energy union was launched on 25 February 2015 (Commission, 2015b), progress made in developing the Trade and Transatlantic Investment Partnership (TTIP), and the digital single market strategy unveiled on 6 May 2015. Measures have also been adopted on fair taxation as part of the deeper and fairer internal market theme, the Commission has attempted to find agreement on a new migration policy with member states, and there has been action on cutting red tape and improving transparency

Second, Juncker has lived up to his promise to defend the Commission. ${ }^{30}$ In contrast to the past when criticisms made by national capitals went unanswered, Juncker has addressed them. When the Italian prime minister opined that even the EU's so-called founding fathers would "become Eurosceptic if faced with "the EU's bureaucrats and bureaucracy", for example, Juncker responded by pointing out that the Commission was a political organization, 
not 'a gang of anonymous bureaucrats' (Gotev, 2015). Then, when speaking about the UK, he observed that: 'Britain is not in a situation to impose its exclusive agenda on other members of the EU. I don't want Britain to leave the EU but I don't want the EU to follow an exclusive British commandership (sic)' (Gotev, 2015).

Third, the Juncker Commission has made a pronounced effort to improve communications. The Commission President and other members of the Commission have been available to meet the press and to address the other institutions, particular the European Parliament. When the 'Luxleaks' scandal emerged, for example, Juncker surprised the European Parliament by appearing personally to defend himself. $^{31}$ The Commission President's informal and self-deprecating style make him accessible, enable him to win trust, and has allowed him to deal lightly with insinuations about his personal habits (Spiegel, 2014b).

Fourth, Juncker has shown considerable tact and diplomacy in sensitive areas of policy. Although he has made clear that there are limits to what he will concede to the UK, he has taken an emollient tone, repeating that he does not want the UK to leave the UK and that he is in favour of a 'fair deal' (Pop, 2015). His appointment of Timmermans as Vice-President for better regulation and nomination of Hill as Commissioner for financial services appear gestures of goodwill to London. Juncker has also avoided unnecessary battles. Although they had run up deficits, the Commission chose not to impose penalties on France or Italy, but instead accepted their promises to reform.

Finally, in keeping with Juncker's reputation as a fixer, there is evidence of effective coordination and relations management behind the scenes. Within the Commission, Juncker's chef de cabinet, Martin Selmayr, has developed a formidable reputation. Between institutions, Juncker maintains close relations with Martin Schulz, who has been described as 'a whip for the "grand coalition" that the Commission President needs to secure a majority in the European Parliament and Gianni Pitella, the head of Socialists and Democrats (Palmeri, 
2015). He also has a good relationship with Donald Tusk, President of the European Council. $^{32}$

\section{CONCLUSION}

Although it has not even reached the midpoint in its term, the Juncker Commission has already made an impact. For observers who expected that the ultimate EU insider would carry on business as usual, the changes he has wrought have been far-reaching. While the full significance of the Spitzenkandidaten process has yet to fully materialize, it appears at first sight to mark yet another victory for the European Parliament. Parliamentary hearings were already a landmark, but the rise of Spitzenkandidaten system give the European Parliament not only the negative power to reject Commissioners, but the ability to choose the Commission President. It constitutes a decisive and perhaps irrevocable shift in the EU's institutional balance from a system centred on the European Council to a parliamentary model, with the accompanying 'perils' (Majone, 2002). Certainly, Juncker's pronouncements seem to make clear that he considers the European Parliament to be the source of his legitimacy. $^{33}$

Meanwhile, Juncker's overhaul of the Commission, its organization and working methods, has been radical. Though not quite as revolutionary as the method of his appointment, it is doubtful that such wide-ranging change could have been possible without the electoral mandate that Juncker is able to claim. In strengthening the collective leadership capacity of the College, Juncker has addressed long-standing problems in the Commission's operation. There are many reasons why the experiment may not work, but Juncker has shown vision, courage and imagination in his gamble on a 'political Commission'.

Furthermore, Juncker has not only entered office with a mandate that none of his predecessors enjoyed, but despite his protestations to the contrary, ${ }^{34}$ has greater command over its operation than previous Commission Presidents. The power of the Commission 
Presidency has been transformed from 'scarcely a job at all' (Campbell, 1983: 181) into a powerful leadership position. José Manuel Barroso was responsible for significantly strengthening the office. However, whereas his immediate predecessor was able to pick priorities and to exercise unprecedented power over policy (Kassim et al, 2015), Juncker drafted, campaigned and was elected on his own programme, appointed members of the College to deliver it, and restructured the Commission around it.

Finally, the Juncker Presidency has a wider conceptual importance. The Spitzenkandidaten has changed more than the selection procedure. As well as tying the Commission Presidency more closely to the European Parliament, it grants a powerful personal mandate to the incoming incumbent, continuing the process by which the holder of the office has grown in pre-eminence that was initiated by the Treaty of Amsterdam (Kassim et al, 2015), and bestows a claim to legitimacy to the head of an international administration that is unique in transnational governance. Moreover, contrary to the assertions from a more structuralist perspective, the experience of the Juncker Presidency, like the Barroso Presidency before it, shows that there remains scope for agency, even within a dense and complex institutional space, and when the climate for EU action has become increasingly hostile.

\section{Acknowledgment}

I should like to thank the officeholders in the European Commission who kindly agreed to answer my questions on a strictly non-attributable basis about the operation of the new Commission in interviews in Brussels between March and July 2015 as part of the research for this article. I am also grateful to Sara Connolly, and to two anonymous referees, who offered comments on an earlier version, and to two members of Commission staff who read the original draft. The usual disclaimer applies.

\section{References}


Barber, T. (2014) 'Juncker's triumph would be revolutionary for the EU', Financial Times, 22 June.

http://www.ft.com/cms/s/0/988887d2-f860-11e3-815f-00144feabdc0.html\#axzz3hMpBfZLf

Bertonchini, Y. (2014) 'The Juncker Commission: What party balances?', Euractiv, http://www.euractiv.com/sections/eu-priorities-2020/juncker-commission-what-partybalances-309395, accessed 22 October 2014

Christiansen, T. (2015) 'European Integration after the 'Spitzenkandidaten': The New Dynamics of EU Leadership Change', integration 1/2015, http://iepberlin.de/en/publications/integration-12015/

Commission (2013) Commission Recommendation of 12 March 2013 on enhancing the democratic and efficient conduct of the elections to the European Parliament Support for a candidate for President of the European Commission, C(2013) 1303 final, 12.03.2013, http://ec.europa.eu/justice/citizen/document/files/c_2013_1303_en.pdf

Commission (2014a) The Juncker Commission: A strong and experienced team standing for change, Brussels, 10.09.2014, IP/14/984, http://europa.eu/rapid/press-release_IP-14984_en.htm.

Commission (2014b) Questions and Answers: The Juncker Commission, MEMO Brussels, 10.09.2014, http://europa.eu/rapid/press-release_MEMO-14-523_en.htm

Commission (2014c) An Investment Plan for Europe, COM(2014) 903 final, 26 November 2014.

Commission (2015) A Digital Single Market Strategy for Europe, COM(2015) 192 final, 6 May 2015.

Commission (2015), Commission Work Programme 2015 A New Start /* COM/2014/0910 final, 16.12.2014 $\operatorname{COM}(2014) \quad 910$ final, http://eur-lex.europa.eu/legalcontent/EN/TXT/?uri=CELEX:52014DC0910

Connolly, S. and Kassim, H. (2015) European Commission: Facing the Future, report available at https://www.uea.ac.uk/documents/241631/0/The+European+Commison++Facing+the+Future-vPEilblH.pdf/13dabbee-7981-45ff-b693-1668e169510e, checked 4 December 2015

EuroParl TV (2015) "'Spitzenkandidaten": the underlying story', http://europarltv.europa.eu/en/player.aspx?pid=39f3a116-e84a-4014-a182-a49f010746ec

European Council (2014) European Council Decision of 23 October 2014 appointing the European Commission (2014/749/EU), http://eur-lex.europa.eu/legal- 
content/EN/TXT/?uri=CELEX:32014D0749

European Parliament (2012) Resolution of 22 November 2012 on Elections to the European Parliament in 2014, 2012/2829(RSP)

European Parliamentary Research Service (2014) 'What an Extraordinary Year for the EU: EPRS-EUI Conference On 2014' http://epthinktank.eu/2014/12/16/what-anextraordinary-year-for-the-eu-eprs-eui-conference-on-2014/

European People's Party (2014) Factsheet: the story of the "Spitzenkandidaten", http://juncker.epp.eu/sites/default/files/attachments/facstheetstoryofspitzenkandidatenfinal.pdf

Gotev, G. (2014) 'Juncker: I will always respond to unfair criticism from national EU leaders', EurActiv, 05 November 2014 - 16:47 updated: 8 January 2015 - 15:45

Grant, C. (2014) 'The new European Commission: which president, and what priorities? - See more at: http://www.cer.org.uk/insights/new-european-commission-which-president-andwhat-priorities\#sthash.Tabu9A6S.dpuf', Centre for European Reform, http://www.cer.org.uk/insights/new-european-commission-which-president-and-whatpriorities, accessed 30 May 2014.

Helms, L. (this issue) 'Introduction: Leadership Questions in Transnational European Governance'.

Hix, S. (2002) 'Constitutional Agenda-Setting Through Discretion in Rule Interpretation: Why the European Parliament Won at Amsterdam', British Journal of Political Science 32: $259-280$.

Juncker, J-C. (2014a) A New Start for Europe: My Agenda for Jobs, Growth, Fairness and Democratic Change. Political Guidelines for the next European Commission, 15 July 2014, http://ec.europa.eu/about/juncker-commission/docs/pg_en.pdf

Juncker, J-C. (2014b) 'The Juncker Commission: The Right Team to Deliver Change', press conference, Brussels, 10 September, SPEECH/14/585, http://europa.eu/rapid/pressrelease_SPEECH-14-585_en.htm

Juncker, J-C. (2014c) 'Time for Action - Statement in the European Parliament plenary session ahead of the vote on the College', 22 October 2014, SPEECH/14/1525 http://europa.eu/rapid/press-release_SPEECH-14-1525_en.htm?locale=FR

Juncker, J-C. et al (2015) 'Completing Europe's Economic and Monetary Union', http://ec.europa.eu/priorities/economic-monetary-union/docs/5-presidents-report_en.pdf

Kassim, H. (2012) 'The Presidents and Presidency of the European Commission' in E. Jones, A. Menon, and S. Weatherill (eds.) The Oxford Handbook of the EU (Oxford: Oxford 
University Press), pp. 219-32

Kassim, H., Peterson, J., Bauer, M.W., Connolly, S., Dehousse, R., Hooghe, L. and Thompson, A. (2013) The European Commission of the Twenty-First Century, Oxford: Oxford University Press.

Kassim, H., Connolly, S. Dehousse, R. and Rozenberg, O. (2015) 'Managing the House: the Presidency, agenda control and policy activism in the European Commission', unpublished mimeo.

Keating, D. (2014) 'Commission unveils 2015 work programme', European Voice, http://www.politico.eu/article/commission-unveils-2015-work-programme/, accessed 16 December 2014.

Keating, D. (2015) 'Energy Union: who's the boss?', European Voice, http://www.politico.eu/article/energy-union-whos-the-boss/, accessed 19 May 2015.

Kocharov, A. (2014) 'This Time It's Different? Constitutional Complexities of the Spitzenkandidaten Arrangement', Freie Universität Berlin, Berlin e-Working Papers on European Law, 2014/95.

Majone, G. (1996) 'Regulatory Legitimacy’, in G. Majone (ed.) Regulating Europe, London: Routledge, pp. 284-301

Majone, G. (1998) 'Europe's Democratic Deficit. The question of standards', European Law Journal, 4(1): 5-28.

Majone, G. (2002) 'The European Commission: The Limits of Centralization and the Perils of Parliamentarization', Governance 15(3): 375-392.

Palmeri, T. (2015) 'The most exclusive dining club in Brussels. Inside the G5 where 'the best jokes are told' and major EU policies are pre-cooked', Politico, http://www.politico.eu/article/g5-brussels-most-exclusive-dining-club/, accessed 18 June 2015.

Pop, V. (2015) 'Let's Get Political. Juncker-Style', Wall Street Journal, http://blogs.wsj.com/brussels/2015/05/07/lets-get-political-juncker-style/, accessed 7 May 2015.

Rinaldi, D. (2014) 'Commissioners as Competitors - Competition and Policy Coherence in the Juncker's Commission', blog of the College of Europe, http://blog.coleurope.eu/2014/09/12/eu-commissioners-as-competitors-in-the-junckerscommission/, accessed 12 September 2014.

Schimmelfennig, F. (2014) 'The Spitzenkandidaten plot: the European Parliament as a strategic competence maximizer', Dublin European Institute blog, 
http://europedebate.ie/spitzenkandidaten-plot-european-parliamentstrategic-competence-maximizer/

Spiegel, P. (2014a) 'Europe's leaders divided on how to pick next EC president', Financial

Times, $\quad$ http://www.ft.com/cms/s/0/0607ca9e-6bf2-11e3-85b1-00144feabdc0.html, 2 January.

Spiegel, P. (2014b) 'Who will gain power in the EU's post 'earthquake' world?', Financial Times, $\quad$ http://www.ft.com/cms/s/0/c124ee14-e583-11e3-8b9000144feabdc0.html\#axzz3hMpBfZLf, 27 May.

Spiegel, P. (2014c) 'Q\&A: The fight over Jean-Claude Juncker and why it matters', Financial Times, http://www.ft.com/cms/s/2/fc0fbd52-f7c0-11e3-b2cf00144feabdc0.html\#axzz3hMpBfZLf, 10 June.

Wagstyl, S. (2014) 'Merkel swaps back to supporting Juncker', Financial Times, http://www.ft.com/cms/s/0/539b1c68-e7d3-11e3-9af8-

00144feabdc0.html\#axzz3hMpBfZLf, 30 May.

\begin{abstract}
About the Author
Hussein Kassim is Professor of Politics at the University of East Anglia. His research interests lie in EU institutions, EU-member states relations, public policy, and public management in the EU. He is currently working on projects on the European Commission, national narratives and the EU, EU competition policy, and the European administration.
\end{abstract}

\title{
Notes
}

1 Since the creation of the EU, prime ministerial experience has become a de facto requirement for appointment to the Commission Presidency.

2 His resignation from the premiership followed a scandal concerning the intelligence services

3 Barroso was prime minister of Portugal between 2002 and 2004, and leader of the opposition, 1999-2002. He was Minister for Foreign Affairs in the early 1990s, state secretary for foreign affairs 1987-92, and state secretary for home affairs 1985-87. Prodi was prime minister of Italy between 1996 and 1998. Santer was prime minister of Luxembourg from 1984 to 1995. He had been finance minister from 1979 to 1989.

4 He had also held senior positions at the World Bank, the IMF and the EBRD.

5 See Barber (2014).

6 On the rise of the Spitzenkandidaten concept, see EPP (2014), EuroParl TV (2015). 
7 The Treaty of Amsterdam introduced a separate vote of approval for the member states' nominee (new Article 214(2) EC). The Treaty of Nice changed the decision rule in the Council for the approval of all Commissioners from common accord to qualified majority voting.

8 The relevant provision - Article 17(7) TEU - reads as follows: 'Taking into account the elections to the European Parliament and after having held the appropriate consultations, the European Council, acting by a qualified majority, shall propose to the European Parliament a candidate for President of the Commission. This candidate shall be elected by the European Parliament by a majority of its component members. If he does not obtain the required majority, the European Council, acting by a qualified majority, shall within one month propose a new candidate who shall be elected by the European Parliament following the same procedure.'

9 See EPP (2014).

10 The European Conservatives and Reformists (ECR) chose not to select a lead candidate.

11 Britain had blocked the nomination of Jean-Luc Dehaene in 1994 and Guy Verhofstadt in 2004.

12 For Juncker's priorities, see http://juncker.epp.eu/my-priorities

13 See, e.g., Schimmelfennig (2014), Kocharov (2014), Grant (2014)

14 See Kocharov (2014). For earlier examples of competence maximizing on the part of the European Parliament, see Hix (2002). On how the European Parliament's rise and rise differs from national parliaments, see Schimmelfennig (2014).

15 Grant (2014) argues, for example, that it does not offer a genuine choice.

16 Only one debate involved all five, but three involved four and Juncker participated in nine, including with Schultz.

17 Barroso, for example, had insisted in the wake of the 'big bang' enlargement that Commissioners from new and old member states would be equal.

18 The President-elect's transition team was headed by Martin Selmayr, previously head of VicePresident Reding's cabinet and campaign manager for Juncker's presidency bid, and included Clara Martínez Alberola, who has served in President Barroso's cabinet, Natasha Bertaud, who was press officer to Juncker during his campaign, and Luc Tholoniat, previously assistant to Secretary General, Catherine Day.

19 A guiding principle, in the words of one interviewee, was 'you need a thief a catch a thief'.

20 The Hearing procedure is governed by Rule 118 of the Parliament's Rules of Procedure.

21 Barroso, for example, had been blocked from appointing Rocco Buttiglione in 2004 and Rumiana Jeleva, in 2009.

22 The conservative ECR group welcomed the new Commission structure, despite abstaining from the vote. Indeed, Syed Kamall, President of the ECR group, praised Juncker for his plans for 'an integrated structure focused on outcomes'.

23 See details at https://ec.europa.eu/commission/2014-2019 en, checked 4 November 2015

24 As Bertonchini (2014) observes, in spite of the EPP's weaker electoral performance compared 
with 2009 the partisan balance between the Barroso and the Juncker Commission is relatively unchanged. Juncker has 19 members from the centre and centre-right, and nine from the left and centre-left, while Barroso had 21 and 7 respectively. The main differences are the smaller number of ALDE-affiliated members ( 5 rather than 8 ) and the inclusion of an ECR-affiliated member.

25 The letters are available on the Commission's website at

http://ec.europa.eu/archives/juncker-commission/mission/index_en.htm, checked 4 November 2015.

26 An online survey conducted among Commission staff as part of a project led by the current author found that only 12 per cent of respondents believed that the College communicated effectively with the services and only 9 per cent that the Commission communicated effectively with European citizens (Connolly and Kassim, 2015).

27 The cabinets have an important role to play, but they are not only smaller, but also more junior and therefore less experienced than historically as a result of reforms introduced since the early 1990s to limit parachutage.

28 For example, within the energy union group between pollution and energy systems, and within the maritime and environmental protection portfolio.

Between 2009 and 2014, the Barroso Commission proposed an average of 130 new initiatives in each annual work programme, and proposed to withdraw an average of 30.

30 Juncker made clear that he was fearless in this respect: 'I don't want to hide from you that I have the firm intention to respond to all unjustified criticism addressed to the Commission, no matter from where they come. I am not a guy who trembles before the Prime Ministers or before other high instances.'.

31 In a scandal that became known as 'Luxleaks' it emerged that Luxembourg had allowed more than a thousand companies to avoid paying tax. As prime minister of the Grand Duchy from 1995 to 2013, Juncker was embarrassed by the scandal, although he claimed on 12 November 2014 never to have given instructions on any particular dossier. With 77 signatories the Five Star movement, UK Independence Party (UKIP) and the National Front moved a vote of censure against the Commission in the European Parliament. It was defeated with 466 votes against.

32 It is noteworthy that Juncker was charged with preparing the second report on the evolution of economic and monetary union - the so-called 'Five President's Report' (Juncker et al 2015), when Tusk's successor, Herman van Rompuy, had taken the lead in writing the first report (the 'Four Presidents' report') in 2012.

33 Juncker (2014c) declared in his address to the plenary on 22 October 2014: 'I have been elected President of the Commission on the basis of a programme that binds me to the European Parliament. I have a contract with you, Mr President, and with this House, and I intend to abide by the terms of the contract I put before you this summer.' 
34 In his speech on 22 October 2014, Juncker called himself 'the big loser', because 'I have delegated most of my jobs and prerogatives to the Vice-Presidents'. He added: 'I am too old to launch a new career as a dictator'.

Key Quotes - Note to author: Please select 3-5 key quotes from the text.

'...Juncker appears well positioned to fulfil his election promise: to be 'bigger and more ambitious on big things, and smaller and more modest on small things'. P.2.

'...Juncker's appointment was more protracted, more public, and more political than that of previous presidents'. P.4

'...Juncker departed from tradition and looked to recruit seven Vice-Presidents. Whereas the title had been largely honorary in previous Commissions, under Juncker it comes with responsibility for policy coordination, symbolized by reservation of the right of the right to submit agenda items for discussion at meetings of the College to the Vice-Presidents.' . (p.9)

'The test is not whether there are differences among Commissioners with intersecting responsibilities, but whether the policy groups can develop workable and effective policy initiatives that can be driven through by the services'. (p.16)

'While the full significance of the Spitzenkandidaten process has yet to fully materialize, it appears at first sight to mark yet another victory for the European Parliament'. (p.18) 